University of Wollongong

Research Online

Faculty of Engineering and Information

Faculty of Engineering and Information

Sciences - Papers: Part A

Sciences

$1-1-2014$

The relationship between the quality of active frontages and public perceptions of public spaces

Emma Elizabeth Heffernan

Plymouth University, Plymouth UK, eheffern@uow.edu.au

Troy W. Heffernan

Plymouth University, Plymouth UK, troyh@uow.edu.au

Wei Pan

University of Hong Kong

Follow this and additional works at: https://ro.uow.edu.au/eispapers

Part of the Engineering Commons, and the Science and Technology Studies Commons

Research Online is the open access institutional repository for the University of Wollongong. For further information contact the UOW Library: research-pubs@uow.edu.au 


\title{
The relationship between the quality of active frontages and public perceptions of public spaces
}

\begin{abstract}
Active frontages are often advocated in best practice guidance and by local planning authorities. However, little research has been carried out to establish what benefits, if any, active frontages offer. Previous research in this area has been limited to examining observed behaviour rather than analysing public perceptions. This article aims to improve the understanding of the relationship between the quality of an active frontage and public perceptions of the public space the frontage addresses. The research was carried out through a combination of a critical literature review and a questionnaire survey that engaged 152 participants. The participants' perceptions of a range of public spaces in relation to a number of frontages were investigated using comparison and correlation. The results suggest that the quality of an active frontage can significantly affect people's perceptions of a public space in terms of its safety, comfort, sociability and liveliness. Good-quality active frontages can contribute to creating successful public spaces, which can help deliver far-reaching benefits for towns and cities. The findings contribute useful evidence to enhance our understanding of the role of active frontages in urban design and planning.
\end{abstract}

\section{Keywords}

spaces, perceptions, relationship, public, frontages, active, between, quality

\section{Disciplines}

Engineering | Science and Technology Studies

\section{Publication Details}

Heffernan, E., Heffernan, T. \& Pan, W. (2014). The relationship between the quality of active frontages and public perceptions of public spaces. Urban Design International, 19 (1), 92-102. 
Heffernan, E., Heffernan, T. and Pan, W. (2014) The Relationship between the quality of active frontages and public perceptions of public spaces. URBAN DESIGN International, 19 (1) pp.92-102.

\section{THE RELATIONSHIP BETWEEN THE QUALITY OF ACTIVE FRONTAGES AND PUBLIC PERCEPTIONS OF PUBLIC SPACES}

\section{Abstract}

Active frontages are often advocated in best practice guidance and by local planning authorities. However, little research has been carried out to establish what benefits, if any, active frontages offer. Previous research in this area has been limited to examining observed behaviour rather than analysing public perceptions. This paper aims to improve the understanding of the relationship between the quality of an active frontage and public perceptions of the public space the frontage addresses. The research was carried out through a combination of a critical literature review and a questionnaire survey which engaged 152 participants. The participants' perceptions of a range of public spaces in relation to a number of frontages were investigated using comparison and correlation. The results suggest that the quality of an active frontage can significantly affect people's perceptions of a public space in terms of its safety, comfort, sociability and liveliness. Good quality active frontages can contribute to creating successful public spaces, which can help deliver far reaching benefits for towns and cities. The findings contribute useful evidence to enhance our understanding of the role of active frontages in urban design and planning.

Keywords: Active frontage; design guidance; perceptions; public space; urban design. 


\section{INTRODUCTION}

Best practice architecture and urban design guidance and selected local planning policy advocates the provision of active frontages in our town and city centres (Llewelyn Davies, 2007; PCC, 2007; URBED, 2009). However, scant empirical research has been undertaken in this area to establish why active frontages should be provided, if indeed they should, and what benefits, if any, they can bring. Consequently, this important subject area was selected as the focus for this research.

The overall aim of this paper was to establish the relationship between the quality of an active frontage and perceptions of a related public space. The research objectives were to:

1) Explore the factors which contribute to the success of public spaces and the potential benefits of successful public spaces, and

2) Identify the impact of the quality of active frontages on public perceptions of public spaces.

Previous research (Gehl et al, 2006) has adduced that good quality active frontages can contribute to the success of a public space. Successful public spaces are those which are comfortable, sociable, accessible and active (PPS, 2011a) and which are loved by the people who use them (Carr et al, 1992). There are a number of factors which can contribute to the success of public spaces; the literature is reviewed and the success factors for public spaces are consolidated. The paper also considers why we need successful public spaces; they have been found to provide benefits on a number of different levels, therefore, if active frontages really can help to create successful public spaces and deliver these benefits, they are evidently a critical element of the urban design of our towns and cities.

\section{ACTIVE FRONTAGES}

The concept of active frontages has primarily developed through the work of Jan Gehl over the last four decades but has its roots in the work of Jacobs (1961) and Newman (1973). 
The following simple definition is provided within the glossary of 'Safer Places' (ODPM 2004: 103) 'Active frontage - The frontage or edge of a building or space that has windows and doors as opposed to blank walls, fences and garages'. Llewelyn Davies (2007) listed a number of attributes for active frontages in their influential publication 'Urban Design Compendium': frequency of doors and windows; vertical rhythm to the buildings; articulation to building facades and views of lively internal uses. Their facade evaluation scale, developed from the previous work of Gehl (1994), sets out a classification for five grades of active frontage (Table 1).

(Table 1 here)

For the purposes of this paper, a definition which combines elements from the 'Safer Places' definition (ODPM, 2004) with those from the work of Gehl (1994) and the 'Urban Design Compendium' (Llewelyn Davies, 2007) is used, that is: the frontage of a building at ground floor level with frequent doors and windows, details and articulation to the facade and visible internal uses.

The Llewelyn Davies definition suggests that interest, life and vitality in the public realm are the potential benefits of active frontages; however one key justification given in much of the literature for the provision of active frontages is that of safety (ODPM, 2004; Sparks and Chapman 1996). The issue of safety in relation to active frontages is derived from the work of Jane Jacobs (1961). Commonly referred to as natural surveillance is the concept of providing a built environment which allows for interaction between buildings and the spaces they define. The most recent national planning guidance specific to designing for safety and security 'Safer Places: The Planning System and Crime Prevention' (ODPM, 2004) encourages the use of active frontages for these reasons of natural surveillance.

Returning to the more social and sociable aspects of active frontages, in his work of 1977 , Alexander wrote of the need to treat the facade of a building as an entity with volume rather than a line on a plan, to design it as a place in its own right in order to support the social life 
of our towns and cities. 'The building with a lively edge, is connected, part of the social fabric, part of the town, part of the lives of all the people who live and move around it.' (Alexander et al, 1977: 754)

Gehl et al (2006) propose that our requirements for the ground floor facade of a building are significantly different from those of other floors. They suggest this is the case because we have 'close encounters' with the street level facade in a way we do not experience the other facades. They conclude that buildings must 'learn to make meaningful conversation' (p.47) with both public spaces and the people who use them.

\section{PUBLIC SPACE}

CABE (2011) proffer that public spaces are streets, squares and parks that are open and accessible to everyone. This is challenged by Holland et al (2007: 45) 'The 'publicness' of public places is conditional and contingent. Observations have shown that however 'public' a place may be, whether or not it is accessible to you depends to a large extent on who you are-your age, status, and sometimes gender; and the time of day'. For the purposes of this paper, the definition of public space is: an open space, such as a street, square or park, which is accessible to all.

Project for Public Spaces (PPS, 2011a) describe four key qualities of successful public spaces: 'they are accessible; people are engaged in activities there; the space is comfortable and has a good image; and finally, it is a sociable place: one where people meet each other and take people when they come to visit'. This description covers the attributes of successful public spaces, but does not define what it is to be successful. Carr et al (1992) suggest that for a space to be loved by its users, by adding joy to their lives, is what it means to be a success. There is broad consensus across the literature that popularity is central to public spaces being able to perform their role in supporting the social life of cities (Gehl, 2006; JRF, 2011; PPS, 2011a; PPS, 2011b; Townshend et al, 2007). It has been written that public space is the stage upon which the communal life of our towns and cities is set (Carr et 
al, 1992; Gehl, 2006; PPS, 2011a; Sparks and Chapman, 1996) the backdrop for an important part of our everyday lives that is not fulfilled by either our home or work environments. Recent literature has shown that towns and cities with vital and vibrant social and economic lives are also those with good quality, well maintained public spaces (Carmona et al, 2003; CABE and DETR 2001). This message is reinforced within 'Planning Policy Statement 1: Delivering Sustainable Development' (ODPM 2005, p7) 'The condition of our surroundings has a direct impact on the quality of life and the conservation and improvement of the natural and built environment brings social and economic benefit for local communities.'

Successful public spaces have been stated to provide benefits on a number of different levels; from economic benefits such as increased land, property and rental values (CABE and DETR, 2001) to social benefits including providing a forum for social interaction (PPS, 2011b). They include environmental benefits such as support for biodiversity within towns and cities (TfL, 2005) and cultural benefits such as enhancing the unique identity of a place (DETR, 2000), and, finally, health benefits including stress reduction and improved personal health (CABE, 2011). Distilled from the literature, table 2 articulates the potential benefits, the multiplicity of which makes the importance of successful public spaces clear:

(Table 2 here)

A review of the literature has identified a number of factors which can contribute to the success of public spaces; they can be grouped under the following themes: activity; access; conviviality and comfort; distinctiveness; safety; robustness and flexibility (Table 3).

(Table 3 here)

Whilst active frontages are advocated by both best practice guidance for urban design and architecture (Llewelyn Davies, 2007; ODPM, 2004; TfL, 2005) and local authorities through planning policy (PCC, 2007; URBED, 2009), there has been little empirical research into how 
they affect perceptions of public space and behaviour in public space. Three studies are referred to here which illustrate the extent of recent research.

An observational study was carried out in Copenhagen (Gehl et al, 2006) to investigate the connection between pedestrian stays and actions and the design of ground floor facades. The study found that: pedestrian traffic was slower along interesting sections of facade; more people turned their heads towards the active facade and more people stopped in front of the active facade. A previous observational study carried out in Madrid supported the findings of the Copenhagen study (Gehl et al, 2006). What this previous research does not explore however is how active frontages affect public perceptions of public spaces. One study which starts to do this is a study into women's perceptions of fear and the design of the urban environment (Boyle et al, 2011). The findings suggest that spaces designed to encourage active uses were perceived to be safer.

The conclusions of the two observational studies rely on interpreting people's behaviour as opposed to investigating their perceptions. This leaves a clear gap in knowledge in terms of research into the relationship between the quality of an active frontage and perceptions of the public space that frontage relates to. This gap warrants further research into this area.

\section{METHODOLOGY}

This research was carried out through an online questionnaire survey. The use of the questionnaire survey helped to realise the aspiration to gather a significant number of responses, and to avoid interviewer bias (Gillham, 2000). Online surveys are particularly suited to collecting data on attitudes (Robson, 2002). The questionnaire went through two stages of pre-testing.

Photographs of a variety of public spaces were taken, from which four pairs were selected by a panel of experts from the field of architecture. The panel rated the level of active frontage shown in each of the photographs (Table 4) using the facade evaluation scale from The Urban Design Compendium (Llewelyn Davies, 2007) (Table 1).; Previous research has 
shown a close link between respondents' opinions expressed on location and those expressed in response to photos (Groat, 1988); this supports the use of photographic images within the online questionnaire. A recent study into aesthetic preferences used photographic images of street elevations in a similar way (Gjerde, 2011). Photographs were also used to measure formal indicators of social urban sustainability and make comparisons between two urban centres in Australia (Porta and Renne, 2005). Nelessen's visual preference survey is one of the most prominent visual assessment methods used within urban design and planning practice for the purposes of community engagement (Bailey et al, 2007). The methodology requires participants to rank photographs of places and spaces in order to articulate the impressions of residents in relation to their community (Al-Kodmany, 2001). Nelessen states that images need to reflect what people would see within the study area, including, inter alia, landscaping, streetscape elements and level of human activity (Nelessen, 1994). Two different versions of the questionnaire were produced using the different photographs of the spaces (Survey 1 and Survey 2: Figure 1); the purpose of which was to determine whether there was a difference in perceptions based on the rating of active frontage for that image. A number of scenario questions were asked in relation to each photo using both semantic differential scales and Likert scales.

(Figure 1 here)

(Table 4 here)

The study used a combination of convenience and snowball sampling. 170 people were initially invited to complete the questionnaire and to forward it to others for completion. A total of 152 people were engaged through the survey. Within the study the gender split was relatively even ( $57.1 \%$ female respondents). The mean age of respondents was 41 years.

The dataset was analysed using SPSS18. Independent sample t-tests were used to compare the means and identify significant differences across the two questionnaires. A 
linear correlation was also carried out to identify the relationship between the active frontage rating and the respondents' perceptions of each of the public spaces.

\section{RESULTS AND ANALYSIS}

The findings in relation to each of the four public spaces used within the questionnaire are considered individually and patterns within the findings are then discussed.

\section{Space $w$}

Figure 2 shows the pair of photos of Space $w$. Image w1 has an active frontage rating (AFR) of 2.44 and image w2 has an AFR of 3.33 .

(Figure 2 here)

(Table 5 here)

As can be seen within table 5 , there were significant differences between the two surveys for five of the semantic pairs: unfriendly-sociable; relaxing-exciting; sleepy-lively, active-dormant and boring-interesting. The means for each of the surveys show therefore that the image of space $w$ used within Survey 2 (with the better active frontage rating) was perceived to be significantly more lively, sociable, exciting, active and interesting than the image of the same space used within Survey 1 (with the poorer active frontage rating). The only statement to provide a significant difference on the Likert scale was 'This space makes me feel at ease'.

\section{Space $x$}

(Figure 3 here)

(Table 6 here)

Table 6 shows that there were significant differences for each of the semantic pairs for Space $x$. From the image used within Survey 1 (with the better active frontage rating), the space was perceived to be more safe, comfortable, lively, sociable, noisy, pleasant, exciting, convivial, active and interesting than in Survey 2. 
(Table 7 here)

As illustrated in table 7, there were also significant differences for each of the likert statements for Space $x$. Significantly more people from Survey 1 than Survey 2 agreed with each of the statements to a greater degree.

\section{Space $y$}

(Figure 4 here)

There were significant differences between Survey 1 and 2 for all of the semantic differential pairs for Space y. Very significant differences on the Likert scale were identified between the means of the two surveys for four of the five statements with the exception of " $/$ would come here at night.

\section{Space z}

(Figure 5 here)

The means for the two surveys indicate that the perceptions of the space in Survey 1 (with the better active frontage rating) were that it was less sociable, peaceful, pleasant and interesting than in Survey 2. There were significant differences in the means on the Likert scale for three of the statements; 'This space makes me feel at ease', 'I would meet my friends here' and 'I would come back here' with more respondents agreeing with these statements to a greater degree in Survey 2 than in Survey 1.

There is a consistent pattern of the photographic image with the better active frontage rating being favoured, with the exception of space $z$, The Southbank in London. This is a notable exception and one for which an explanation can be postulated: it has been highlighted in the literature that a space could be poorly designed, but, due to its location and linkages, be lively and popular (Jacobs 1961). That is not to say that The Southbank is poorly designed, however it does not benefit from all of the success factors identified within the literature, more specifically, in many places there is no active frontage. However, its other benefits, 
such as the river, views, open space and activity, far outweigh the lack of active frontage and this is shown in the findings. In all other cases, the public space within the image with the better active frontage rating is perceived to be more sociable, interesting, comfortable, pleasant, convivial and safe.

\section{Active Frontages and Public Perceptions of Public Spaces}

A linear correlation was carried out to identify the relationship between the active frontage rating and the respondents' perceptions of each of the spaces. Table 8 illustrates the findings.

(Table 8 here)

All but one pair of variables was found to have a very significant relationship; the exception is that the Relaxing-Exciting semantic differential pair does not vary significantly in relation to the quality of the active frontage $(r=0.039)$. The strongest relationship is that between the semantic pair Active-Dormant and the rating of the active frontage $(r=-0.329)$. The negative value indicates that as the active frontage rating increases, the mean of the perception on the Active-Dormant scale decreases, ie. the higher the quality of active frontage, the more active the space is perceived to be. Other strong findings include the relationship between the active frontage rating and perceptions of a space on the Comfortable-Uncomfortable scale $(r=-0.319)$ with respondents' perceptions that a space is comfortable increasing with the quality of active frontage of that space and the relationship between the active frontage rating and perceptions of a space on the Safe-Unsafe scale $(r=-0.305)$ with respondent's perceptions of safety increasing as the quality of active frontage increases.

\section{DISCUSSION AND CONCLUSIONS}

The overall aim of this research was to improve the understanding of the relationship between the quality of active frontages and perceptions of public spaces. From the literature, this paper has shown that the success of public spaces is a somewhat intangible phenomenon, definable through its qualities rather than any specific measure. However, 
there appears to be some agreement that successful public spaces are accessible, active, comfortable and sociable (Gehl et al, 2006; PPS, 2011a; PPS, 2011b; Townshend et al, 2007). Scant research has been carried out into active frontages, their impacts, potential benefits or their relationship with the public spaces they address; therefore, a clear gap in the literature existed which this study has been able to address.

The research found that there was a relationship between the quality of an active frontage and respondents' perceptions of a space. As the quality of active frontage increased, so did the perception that the space was more: safe, comfortable, lively, sociable, pleasant, convivial, active and interesting. This research therefore supports the stance of selected local planning policy and guidance (Llewelyn Davies, 2007; PCC, 2007) that active frontages should be provided as part of good quality design solutions. Whilst the scope of this paper expands on previous studies, the findings also support those of the previous observational studies (e.g. Gehl et al, 2006) that the public are more interested in and more comfortable in the context of better quality active frontages. The findings of this research also support the classifications within the façade evaluation scale (Table 1) (Llewelyn Davies, 2007). Therefore, the use of this scale as both a design and planning tool is supported. Not all spaces will warrant being enclosed by a building with a very high active frontage rating. However, given the findings of the research it would appear inappropriate for any building with a very poor active frontage rating to be designed to enclose a public space. A recommendation for future research is therefore to identify under which conditions the various grades of active frontage are appropriate. This will provide further depth to the façade evaluation scale and would be of use to both design and planning practitioners.

Of the seven public space success factors identified from the literature (Table 3), the findings from this research suggest that the quality of active frontage relating to a public space will impact not only on its safety, but also its activity, conviviality and comfort. Therefore, a contribution of this research would be to add to the conceptualisation of the literature. Thus, 
in future, Table 3 could be updated to include the provision of active frontages under the detailed requirements for these additional success factors.

As with all research, this study is subject to limitations. The photographs used within the survey contained differing levels of pedestrian activity within them. This may have influenced the responses of participants and is therefore a limitation of the research. Any future research or replication of this study should look to address this in order to identify whether the results are indeed affected. The sample group was predominantly based in South West England and the photographs used illustrate a selection of spaces in Greater London. Whilst these limitations of geography and sample demographic exist, it is thought that the findings of this paper should be of interest to other researchers and practitioners as they augment the existing limited research in this area. Future research could address these geographical limitations with research carried out in a different region or on a national or international level. Future research could also further investigate public perceptions using qualitative techniques.

The quality of an active frontage has been shown to impact upon the perceptions of the public space to which that frontage relates. Given the potential benefits of successful public spaces exposed through the literature, active frontages which create meaningful relationships with the public spaces they address should be encouraged.

\section{REFERENCES}

Alexander, C., Ishikawa, S., Silverstein, M. with Jacobson, M., Fiksdahl-King, I. and Angel, S. (1977) A Pattern Language. New York: Oxford University Press.

Al-Kodmany, K. (2001) Visualization Tools and Methods for Participatory Planning and Design, Journal of Urban Technology, 8 (2): 1-37. 
Bailey, K., Grossardt, T. and Pride-Wells, M. (2007) Community design of light rail transitoriented development using casewise visual evaluation (CAVE), Socio-Economic Planning Sciences, 41: 235-254.

Bentley, I., Alcock, A., Murrain, P., McGlynn, S. and Smith, G. (1985) Responsive Environments: a manual for designers, London: Architectural Press.

Boyle, J., Findlay, C. and Forsyth, L. (2011) An Investigation into Women's Perceptions of Fear and the Design of the Urban Environment, http://www.openspace.eca.ac.uk/conference/proceedings/PDF/Forsth.pdf, accessed 24 January 2011.

CABE (Commission for Architecture and the Built Environment) (2011) Public space benefits, http://www.cabe.org.uk/sustainable-places/public-space/benefits, accessed 10 March 2011.

CABE and DETR (Department for Environment, Transport and the Regions) (2001) The value of urban design: a research project commissioned by CABE and DETR to examine the value added by good urban design. London: Thomas Telford Publishing.

Carmona, M., Heath, T., Oc, T. and Tiesdell, S. (2003) Public Places, Urban Spaces. Oxford: Architectural Press.

Carr, S., Francis, M., Rivlin, L. and Stone, A. (1992) Public Space. Cambridge: Cambridge University Press.

CLG (Department for Communities and Local Government), DfT (Department for Transport) and Welsh Assembly (2007) Manual for Streets. London: Thomas Telford.

DETR (2000) By Design: Urban design in the planning system: towards better practice. Norwich: HMSO. 
DoE (Department of the Environment) (1994) Vital and Viable Town Centres: Meeting the Challenge. Norwich: HMSO.

Gehl, J. (1994) Places for People. Melbourne: Melbourne City Council.

Gehl, J. (2006) Life Between Buildings, Using Public Space, $6^{\text {th }}$ edition. Skive: The Danish Architectural Press.

Gehl, J., Kaefer, L. J. and Reigstad, S. (2006) Close encounters with buildings. Urban Design International 11: 29-47.

Giddings, B., Charlton, J. and Horne, M. (2011) Public squares in European city centres. Urban Design International 16 (3): 202-212.

Gillham, B. (2000) Developing a Questionnaire. London: Continuum.

Gjerde, M. (2011) Visual evaluation of urban streetscapes: How do public preferences reconcile with those held by experts?, Urban Design International, 16 (3): 153-161.

Groat, L. (1988) 'Contextual compatibility in architecture: An issue of personal taste?' In: Nasar, J. L. (ed.) Environmental Aesthetics: Theory, Research and Applications. Cambridge: Cambridge University Press, pp. 228-257.

Holland, C., Clark, A., Katz, J. and Peace, S. (2007) Social interactions in urban public places. Bristol: The Policy Press.

Jacobs, J. (1961) The Death and Life of Great American Cities. New York: Random House. Llewellyn Davies (2007) Urban Design Compendium. London: English Partnerships. Miles, M. (1997) Art Space and the City: public art and urban futures. London: Routledge. Nelessen, A. (1994) Visions for a New American dream: process, principles, and an ordinance to plan and design small communities. Chicago: American Planning Association Press. 
Newman, O. (1973) Defensible Space: People and Design in the Violent City. London: Architectural Press.

ODPM (Office of the Deputy Prime Minister) (2004) Safer Places: The planning system and crime prevention. Norwich: HMSO.

PCC (Plymouth City Council) (2007) Local Development Framework: Core Strategy 20062021. Plymouth: Plymouth City Council.

Porta, S. and Renne, J. L. (2005) Linking urban design to sustainability: formal indicators of social urban sustainability field research in Perth, Western Australia, Urban Design International, 10 (1): 51-64.

PPS (Project for Public Spaces) (2011a) What Makes a Successful Place? http://www.pps.org/articles/grplacefeat/, accessed 25 February 2011.

PPS (2011b) What is a Great Civic Space?

http://www.pps.org/articles/benefits_public_spaces/, accessed 25 February 2011.

Robson, C. (2002) Real World Research, $2^{\text {nd }}$ edition. Oxford: Blackwell Publishing Sparks, L. and Chapman, D. (1996) Environment and Space, in D. Chapman (ed) Creating neighbourhoods and places in the built environment. London: E \& FN Spon.

TfL (Transport for London) (2005) Improving walkability: Good practice guidance on improving pedestrian conditions as part of development opportunities. London: Transport for London.

Townshend, T., Hassler, J., Madanipour, A., Jackson, S. and Roe, M. (2007) Public Space Vitality: in the North East Region. Newcastle: One North East, Culture Northeast and Global Urban Research Unit.

Urban Task Force (1999) Towards an Urban Renaissance: Final report of the Urban Task Force Chaired by Lord Rogers of Riverside. Norwich: HMSO. 
URBED (2009) Nottingham City Centre Urban Design Guide. Nottingham: Nottingham City Council.

Whyte, W. H. (1980) The social life of small urban spaces. Washington DC: Conservation Foundation.

Word count: 5,925 including all tables and references

Date of manuscript: $27^{\text {th }}$ June 2013 
TABLES, FIGURES AND PLATES

\section{Grade A frontage}

-> 15 premises every $100 \mathrm{~m}$

- $>25$ doors and windows every $100 \mathrm{~m}$

surface

- A large range of functions

\section{Grade B frontage}

-10-15 premises every $100 \mathrm{~m}$

- > 15 doors and windows

every $100 \mathrm{~m}$

- A moderate range of functions

\section{Grade $\mathbf{C}$ frontage}

- 6-10 premises every $100 \mathrm{~m}$

- Some range of functions

- < half blind or passive facades

\section{Grade $D$ frontage}

- 3-5 premises every $100 \mathrm{~m}$

- Little or no range of functions

- Predominantly blind or passive facades

\section{Grade E frontage}

-1-2 premises every $100 \mathrm{~m}$

- No range of functions

- Predominantly blind or passive facades
- No blind facades and few passive ones

- Much depth and relief in the building

- High quality materials and refined details

- A few blind or passive facades

- Some depth and modelling in the building surface

- Good quality materials and refined details

- Very little depth and modelling in the building surface

- Standard materials and few details

- Flat building surfaces

- Few or no details

- Flat building surfaces

- No details and nothing to look at

Table 1: Facade evaluation scale (Llewelyn Davies, 200; after Gehl, 1994) 


\begin{tabular}{|c|c|c|}
\hline & Benefits & References \\
\hline Social benefits & $\begin{array}{l}\text { - } \quad \text { Reduced pollution and better health through } \\
\text { encouraging walking and other sustainable } \\
\text { modes of transport; } \\
\text { - } \quad \text { Reduced stress; } \\
\text { - } \quad \text { Less crime and fear of crime; } \\
\text { - } \quad \text { Enhanced civic pride; } \\
\text { - Inclusive environments; } \\
\text { - } \quad \text { Providing a forum for social interaction; } \\
\text { meeting people - friends, acquaintances or } \\
\text { - } \quad \text { strangers; } \\
\text { - } \quad \text { Better quality of life. }\end{array}$ & $\begin{array}{l}\text { CABE and DETR, } \\
2001 ; \\
\text { Carr et al, 1992; } \\
\text { Giddings et al, 2011; } \\
\text { PPS, 2011b. }\end{array}$ \\
\hline $\begin{array}{l}\text { Economic } \\
\text { benefits }\end{array}$ & $\begin{array}{l}\text { - } \quad \text { Acting as a catalyst to revitalising } \\
\text { neighbourhoods or areas of a town or city to } \\
\text { encourage inward investment; } \\
\text { - } \quad \text { Increased land, property and rental values; } \\
\text { - } \quad \text { Attracting greater numbers of people to an } \\
\text { area thus benefiting the businesses located } \\
\text { there; } \\
\text { - } \quad \text { Reduced maintenance and running costs; }\end{array}$ & $\begin{array}{l}\text { CABE and DETR, } \\
\text { 2001; Giddings et al, } \\
\text { 2011; PPS, 2011b; } \\
\text { TfL, } 2005 \text {. }\end{array}$ \\
\hline $\begin{array}{l}\text { Environmental } \\
\text { benefits }\end{array}$ & $\begin{array}{l}\text { - } \quad \text { Reduced environmental damage; } \\
\text { - } \quad \text { Support for diverse ecology within towns } \\
\text { and cities; } \\
\text { - } \quad \text { Reduced energy consumption; } \\
\text { - } \quad \text { Potential for sustainable urban drainage; } \\
\text { - Help combat urban heat island effect }\end{array}$ & $\begin{array}{l}\text { CABE and DETR, } \\
\text { 2001; Giddings et al, } \\
\text { 2011; PPS, } 2011 \mathrm{~b} \text {; } \\
\text { TfL, } 2005 \text {. }\end{array}$ \\
\hline Cultural benefits & $\begin{array}{l}\text { Providing or enhancing the unique identity } \\
\text { of a place, town or city; } \\
\text { - Providing users with open access to cultural } \\
\text { activities; } \\
\text { - Establishing significance and meaning for } \\
\text { individuals and groups. }\end{array}$ & $\begin{array}{l}\text { Carr et al, 1992; } \\
\text { DETR, 2000; } \\
\text { PPS, 2011b. }\end{array}$ \\
\hline Health benefits & $\begin{array}{l}\text { - Improved personal health through making } \\
\text { walking more attractive; } \\
\text { - Stress reduction through provision of } \\
\text { calming green environment; } \\
\text { - Improved personal and mental health } \\
\text { through social exchange. }\end{array}$ & $\begin{array}{l}\text { CABE, 2011; } \\
\text { TfL, } 2005 .\end{array}$ \\
\hline
\end{tabular}

Table 2: Potential benefits of successful public spaces. 


\begin{tabular}{|c|c|c|c|}
\hline Success factor & Broad requirement & Detailed requirement & References \\
\hline \multirow{5}{*}{ Activity } & People attract people & Uses in and around the space & $\begin{array}{l}\text { Alexander et al, 1977; DoE, 1994; Gehl, 2006; } \\
\text { Jacobs, 1961; PPS, 2011a; Townshend et al, } \\
\text { 2007; Whyte, 1980. }\end{array}$ \\
\hline & \multirow{2}{*}{ Focus activity areas } & $\begin{array}{l}\text { Provide areas for rest, relaxation and people watching } \\
\text { with choices }\end{array}$ & $\begin{array}{l}\text { Bentley et al, 1985; Carr et al, 1992; Gehl, 2006; } \\
\text { PPS, 2011a; Whyte, } 1980 .\end{array}$ \\
\hline & & $\begin{array}{l}\text { Provide areas for activity - markets, cafes, street } \\
\text { performance }\end{array}$ & Carr et al, 1992; PPS, 2011a; Whyte, 1980. \\
\hline & \multirow{2}{*}{ Activities to suit users' needs } & Design for the needs of local community / user group & Carr et al, 1992; PPS, 2011a. \\
\hline & & Design for a diversity of ages and for both sexes & Alexander et al, 1977; PPS, 2011a. \\
\hline \multirow{5}{*}{ Access } & \multirow{3}{*}{ Connectivity \& permeability } & Routes through the space follow desire lines & Bentley et al, 1985, PPS, 2011a. \\
\hline & & Routes beyond the space link attractors and attractions & Bentley et al, 1985, DoE, 1994, PPS, 2011a. \\
\hline & & $\begin{array}{l}\text { Provide visual links - views to and into the space from } \\
\text { long and short distance }\end{array}$ & PPS, 2011a. \\
\hline & \multirow[b]{2}{*}{ Accessibility } & Provide an accessible environment for all & DoE, 1994, PPS, 2011a,Townshend et al, 2007. \\
\hline & & Provide a legible environment & $\begin{array}{l}\text { Bentley et al, 1985; DETR, 2000; DoE, 1994; } \\
\text { PPS, 2011a; Sparks and Chapman, 1996; } \\
\text { Townshend et al, } 2007 .\end{array}$ \\
\hline \multirow{6}{*}{ Convivialty \& Comfort } & \multirow{5}{*}{ Pleasant to use } & Provide for social interaction & $\begin{array}{l}\text { Bentley et al, 1985; Jacobs, 1961; PPS, 2011a; } \\
\text { Townshend et al, } 2007 .\end{array}$ \\
\hline & & Provide refuge from traffic noise and pollution & PPS, 2011a; Whyte 1980. \\
\hline & & Avoid clutter & Llewelyn Davies, 2007. \\
\hline & & Provide shelter, shade and sun to suit the microclimate & $\begin{array}{l}\text { Carr et al, 1992; PPS, 2011a; Sparks and } \\
\text { Chapman, 1996; Whyte, } 1980 .\end{array}$ \\
\hline & & Provide seating - choice of type and locations & Whyte, 1980. \\
\hline & Stimulate the senses & Provide stimulation for all senses: touch, smell \& sound & Llewelyn Davies, 2007. \\
\hline \multirow{5}{*}{ Distinctiveness } & \multirow{3}{*}{ Strengthen local identity } & Use local materials & CLG et al, 2007; DETR, 2000; DoE, 1994. \\
\hline & & Plant local species & DoE, 1994; Llewelyn Davies, 2007. \\
\hline & & Use locally distinctive patterns of development & DETR, 2000. \\
\hline & Public Art & Use public art to develop meaning & $\begin{array}{l}\text { Carr et al, 1992; Llewelyn Davies, 2007; Miles, } \\
\text { 1997. }\end{array}$ \\
\hline & Meaning & $\begin{array}{l}\text { Develop meaning through involvement, history, society } \\
\text { and nature }\end{array}$ & Carr et al, 1992; Urban Task Force, 1999. \\
\hline \multirow{3}{*}{ Safety } & \multirow{3}{*}{$\begin{array}{l}\text { Free from crime and fear of } \\
\text { crime }\end{array}$} & Design in natural surveillance & $\begin{array}{l}\text { Alexander et al, 1977; DoE, 1994; Jacobs, 1961; } \\
\text { ODPM, 2004; PPS, 2011a; Sparks and Chapman, } \\
\text { 1996; Whyte, 1980. }\end{array}$ \\
\hline & & Provide active frontages & $\begin{array}{l}\text { Alexander et al, 1977; Bentley et al, 1985; Jacobs, } \\
\text { 1961; PPS, 2011a; Sparks and Chapman, 1996; } \\
\text { Whyte, 1980. }\end{array}$ \\
\hline & & Provide lighting for night-time & Alexander et al, 1977; DoE, 1994; ODPM, 2004. \\
\hline \multirow{2}{*}{ Robustness } & \multirow{2}{*}{ Longevity } & Use quality materials and workmanship & Llewelyn Davies, 2007; Gehl, 2006. \\
\hline & & Maintenance and cleanliness & CLG et al, 2007; DoE, 1994; PPS, 2011a. \\
\hline \multirow{2}{*}{ Flexibilty } & Adaptability & Design for future change & DETR, 2000. \\
\hline & Flexibility of use & Design to allow for a variety of uses within the space & PPS, 2011a. \\
\hline
\end{tabular}

Table 3: Public Space Success Factors 


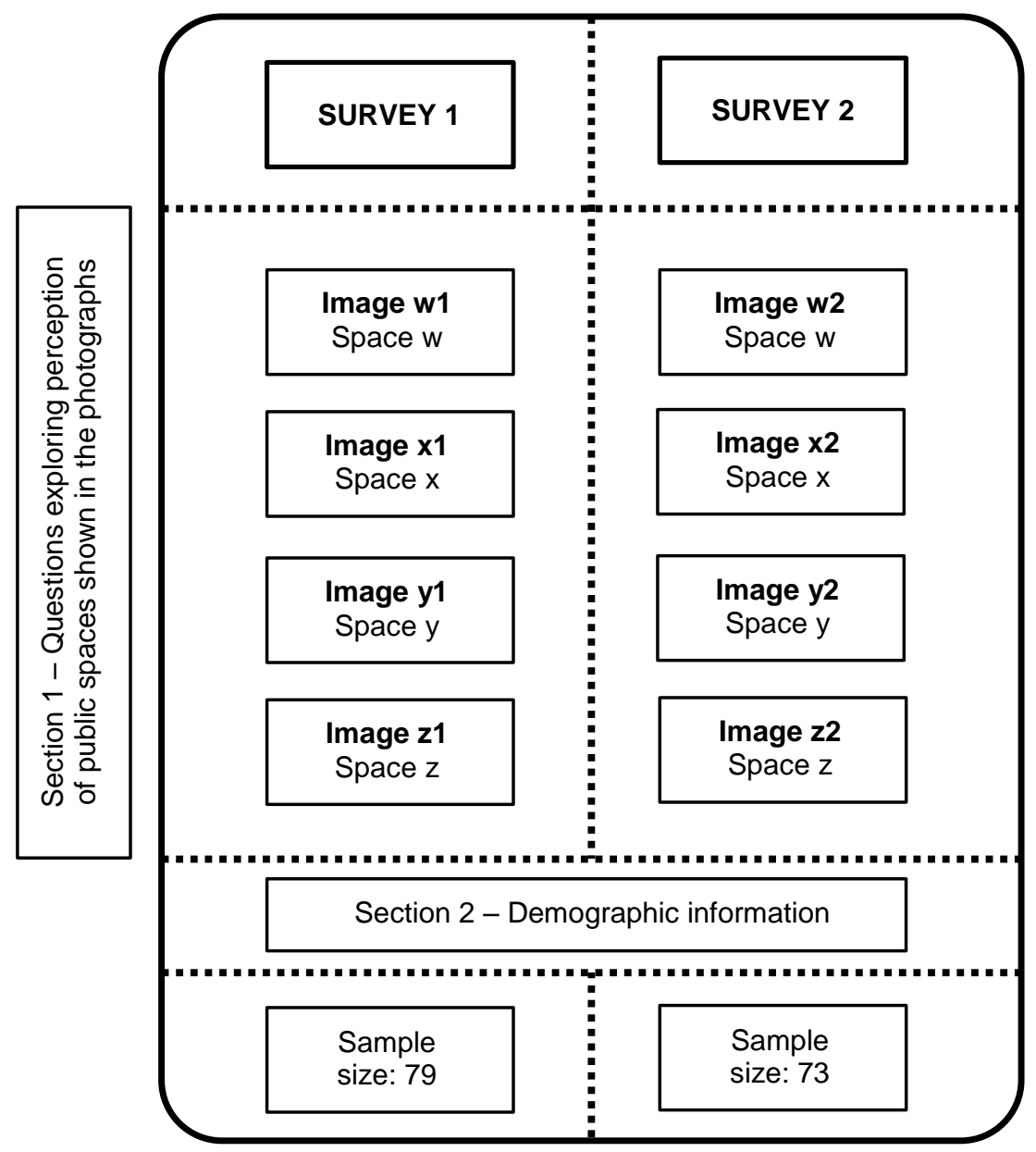

Figure 1: Study structure 


\begin{tabular}{ccccc}
\hline Survey version & Image no. & Space & Mean & Average classification \\
\hline 1 & w1 & w & 2.44 & D \\
2 & w2 & w & 3.33 & C \\
1 & x1 & x & 4.11 & B \\
2 & x2 & x & 2.89 & $\mathrm{C}$ \\
1 & y1 & y & 3.00 & $\mathrm{C}$ \\
2 & y2 & y & 1.44 & E \\
1 & z1 & z & 3.00 & $\mathrm{C}$ \\
2 & $\mathrm{z} 2$ & $\mathrm{z}$ & 2.00 & $\mathrm{D}$ \\
\hline
\end{tabular}

Table 4: Active frontage ratings for each of the images used (the higher the mean rating, the better the quality of active frontage) 

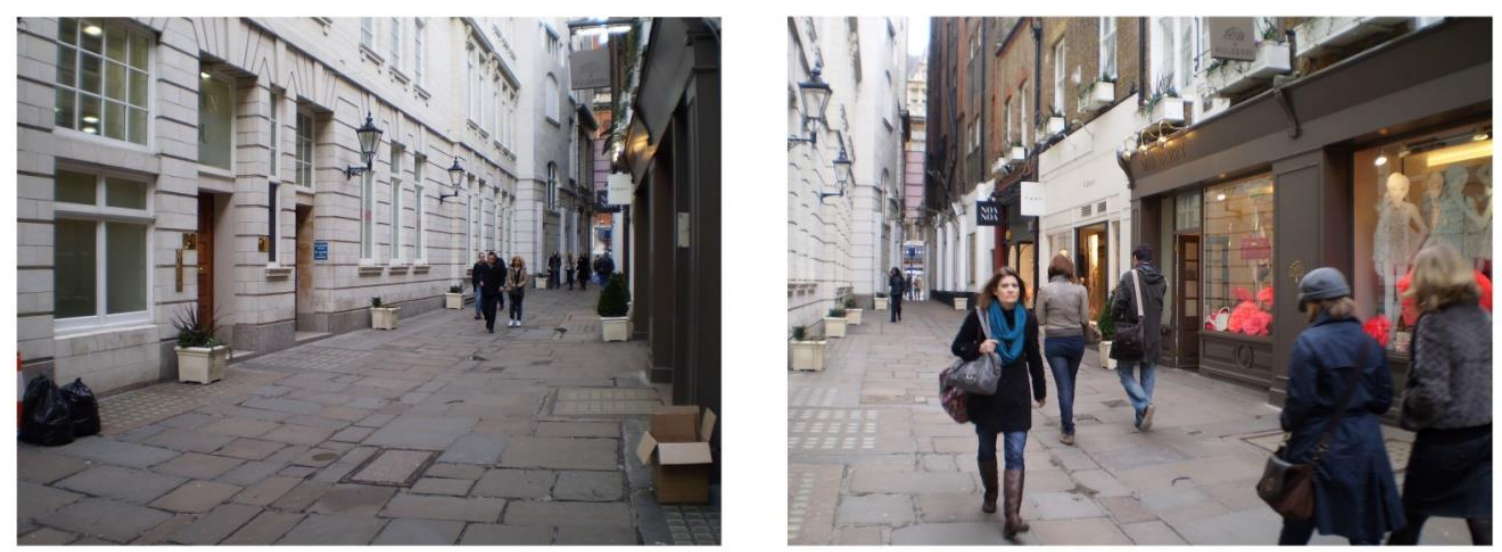

Figure 2: Images w1/ w2, space $w$ 


\begin{tabular}{lcccccc}
\hline & $\begin{array}{c}\text { Survey } \\
\text { version }\end{array}$ & $N$ & Mean & $\begin{array}{c}\text { Mean } \\
\text { difference }\end{array}$ & $t$ & $\begin{array}{c}\text { Significance } \\
\text { (2-tailed) }\end{array}$ \\
\hline Safe-Unsafe & A & 79 & 2.81 & 0.070 & 0.327 & 0.744 \\
Comfortable-Uncomfortable & B & 73 & 2.74 & & & \\
& A & 79 & 3.30 & 0.400 & 1.750 & 0.082 \\
Sleepy-Lively & B & 73 & 2.90 & & & \\
& A & 79 & 3.34 & -0.590 & -2.918 & $0.004^{* *}$ \\
Unfriendly-Sociable & B & 73 & 3.93 & & & \\
Noisy-Peaceful & A & 79 & 3.66 & -0.479 & -2.149 & $0.033^{*}$ \\
Pleasant-Unpleasant & B & 73 & 4.14 & & & \\
Relaxed-Tense & A & 79 & 4.85 & 0.328 & 1.704 & 0.091 \\
Convivial-Dull & B & 73 & 4.52 & & & \\
Active-Dormant & A & 79 & 3.22 & 0.325 & 1.524 & 0.130 \\
Boring-Interesting & B & 73 & 2.89 & & & \\
& A & 79 & 3.28 & -0.420 & -2.436 & $0.016^{*}$ \\
& B & 73 & 3.70 & & & \\
& A & 79 & 4.14 & 0.221 & 0.983 & 0.327 \\
\hline & B & 73 & 3.92 & & & \\
& A & 79 & 4.33 & 0.822 & 3.957 & $0.000^{* *}$ \\
& B & 73 & 3.51 & & & \\
& A & 79 & 3.70 & -0.633 & -2.707 & $0.008^{* *}$ \\
\hline
\end{tabular}

Significance codes: ${ }^{*} p \leq 0.05,{ }^{* \star} p \leq 0.01$

Table 5: Independent Sample t-tests for semantic differential scales - space w 

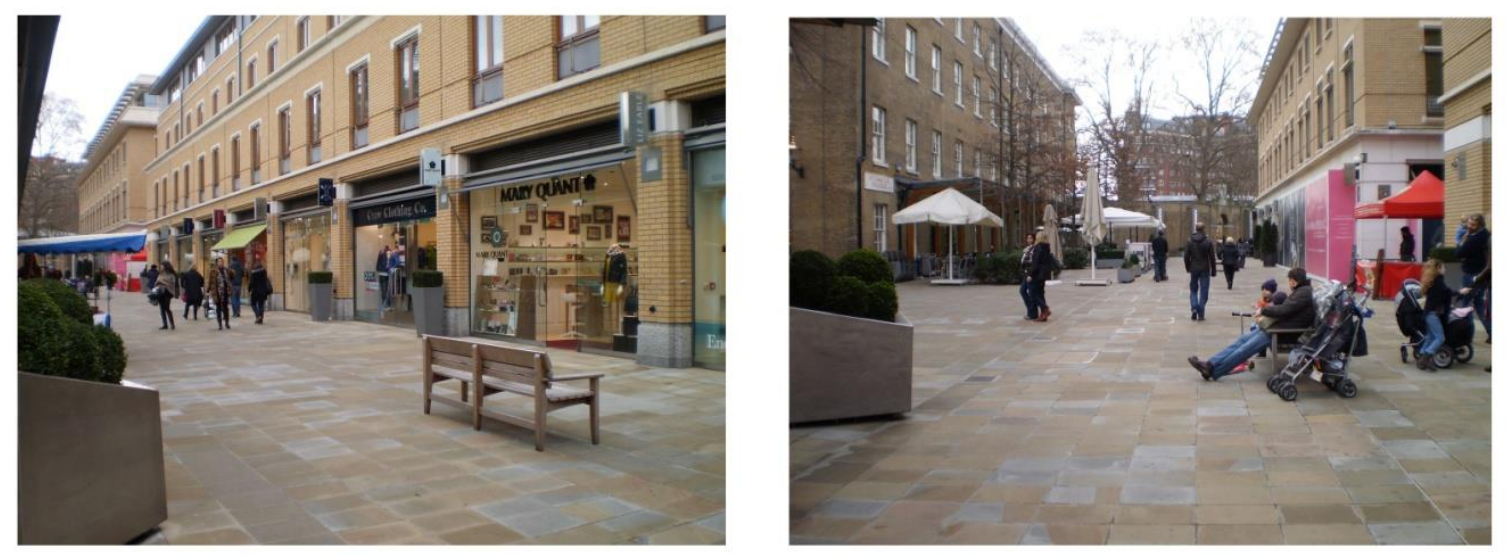

Figure 3: Photos of Space $x$ - Image $x 1$ has an AFR of 4.11 and image $x 2$ has an AFR of 2.89. 


\begin{tabular}{|c|c|c|c|c|c|c|}
\hline & $\begin{array}{l}\text { Survey } \\
\text { version }\end{array}$ & $N$ & Mean & $\begin{array}{c}\text { Mean } \\
\text { difference }\end{array}$ & $t$ & $\begin{array}{c}\text { Significance } \\
\text { (2-tailed) }\end{array}$ \\
\hline Safe-Unsafe & $\begin{array}{l}A \\
B\end{array}$ & $\begin{array}{l}75 \\
70\end{array}$ & $\begin{array}{l}1.97 \\
2.44\end{array}$ & -.470 & -2.804 & $0.006^{* *}$ \\
\hline Comfortable-Uncomfortable & $\begin{array}{l}A \\
B\end{array}$ & $\begin{array}{l}75 \\
70\end{array}$ & $\begin{array}{l}2.35 \\
3.03\end{array}$ & -.682 & -3.331 & $0.001^{\star *}$ \\
\hline Sleepy-Lively & $\begin{array}{l}A \\
B\end{array}$ & $\begin{array}{l}75 \\
70\end{array}$ & $\begin{array}{l}4.72 \\
3.91\end{array}$ & .806 & 4.338 & $0.000^{\star \star}$ \\
\hline Unfriendly-Sociable & $\begin{array}{l}A \\
B\end{array}$ & $\begin{array}{l}75 \\
70\end{array}$ & $\begin{array}{l}4.93 \\
4.37\end{array}$ & .562 & 2.775 & $0.006^{* *}$ \\
\hline Noisy-Peaceful & $\begin{array}{l}A \\
B\end{array}$ & $\begin{array}{l}75 \\
70\end{array}$ & $\begin{array}{l}3.48 \\
4.00\end{array}$ & -.520 & -3.094 & $0.002^{* *}$ \\
\hline Pleasant-Unpleasant & $\begin{array}{l}A \\
B\end{array}$ & $\begin{array}{l}75 \\
70\end{array}$ & $\begin{array}{l}2.83 \\
3.41\end{array}$ & -.588 & -2.852 & $0.005^{\star *}$ \\
\hline Relaxed-Tense & $\begin{array}{l}A \\
B\end{array}$ & $\begin{array}{l}75 \\
70\end{array}$ & $\begin{array}{l}3.95 \\
3.30\end{array}$ & .647 & 3.845 & $0.000^{* *}$ \\
\hline Convivial-Dull & $\begin{array}{l}A \\
B\end{array}$ & $\begin{array}{l}75 \\
70\end{array}$ & $\begin{array}{l}3.44 \\
4.03\end{array}$ & -.589 & -2.743 & $0.007^{\star *}$ \\
\hline Active-Dormant & $\begin{array}{l}A \\
B\end{array}$ & $\begin{array}{l}75 \\
70\end{array}$ & $\begin{array}{l}2.79 \\
3.61\end{array}$ & -.828 & -4.118 & $0.000^{\star *}$ \\
\hline Boring-Interesting & $\begin{array}{l}A \\
B\end{array}$ & $\begin{array}{l}75 \\
70\end{array}$ & $\begin{array}{l}4.37 \\
3.51\end{array}$ & .859 & 3.587 & $0.000^{\star \star}$ \\
\hline
\end{tabular}

Significance codes: ${ }^{*} p \leq 0.05,{ }^{* \star} p \leq 0.01$

Table 6: Independent Sample t-tests for semantic differential scales - space $x$ 


\begin{tabular}{lcccccc}
\hline & $\begin{array}{c}\text { Survey } \\
\text { version }\end{array}$ & $N$ & Mean & $\begin{array}{c}\text { Mean } \\
\text { difference }\end{array}$ & $t$ & $\begin{array}{c}\text { Significance } \\
\text { (2-tailed) }\end{array}$ \\
\hline This space makes me feel at ease & A & 79 & 3.69 & 0.493 & 3.495 & $0.001^{* *}$ \\
& B & 73 & 3.20 & & & \\
I like this space & A & 79 & 3.77 & 0.416 & 2.892 & $0.004^{* *}$ \\
& B & 73 & 3.36 & & & \\
I would come here at night & A & 79 & 3.39 & 0.315 & 2.210 & $0.036^{*}$ \\
& B & 73 & 3.07 & & & \\
I would meet my friends here & A & 79 & 3.33 & 0.362 & 2.371 & $0.019^{*}$ \\
I would come back here & B & 73 & 2.97 & & & 0.049 \\
& A & 79 & 3.64 & 0.269 & 2.019 & $0.045^{*}$ \\
\hline
\end{tabular}

Significance codes: ${ }^{*} p \leq 0.05,{ }^{* *} p \leq 0.01$

Table 7: Independent Samples t-tests for likert scales - space $x$ 

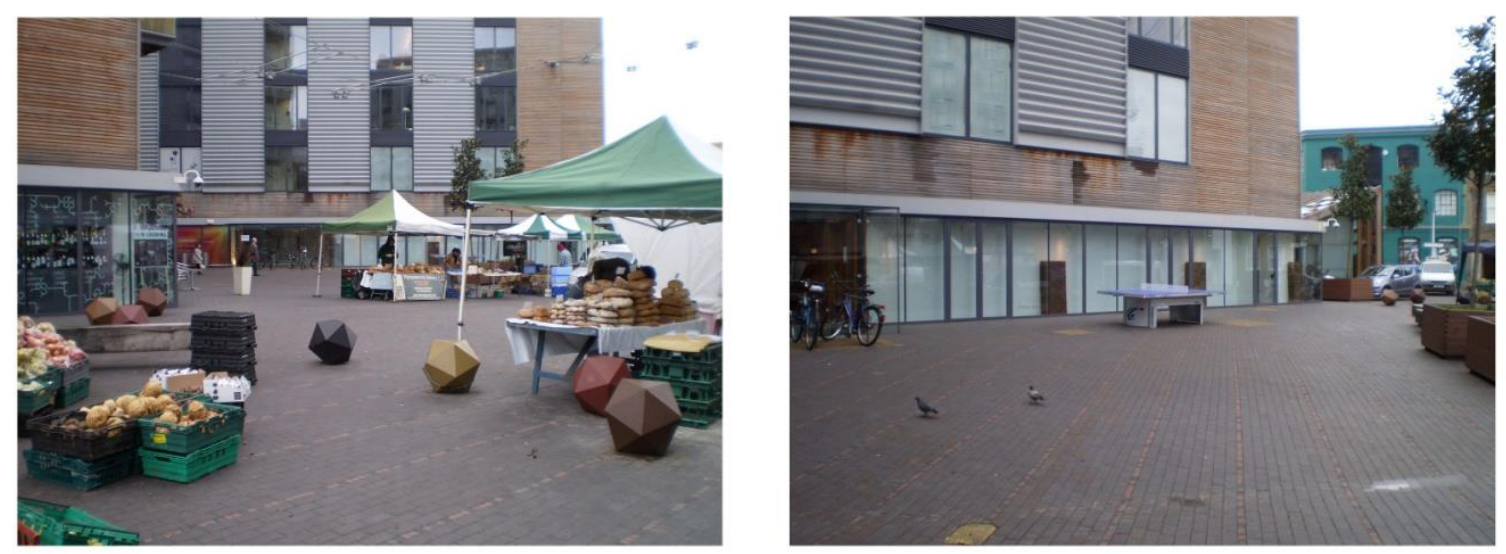

Figure 4: Photos of Space $y$-Image $y 1$ has an AFR of 3.00 and image y2 has an AFR of 1.44. 

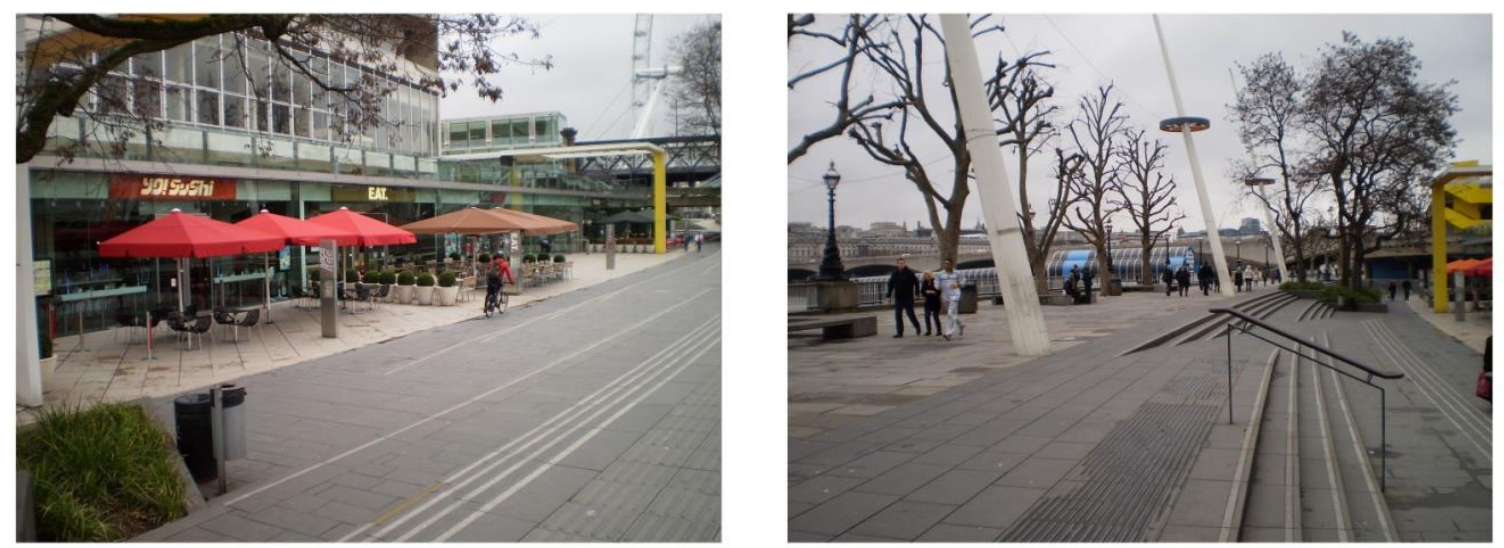

Figure 5: Photos of Space z - Image z1 has an AFR of 3.00 and image z2 has an AFR of 2.00. 


\begin{tabular}{|c|c|c|}
\hline & $\begin{array}{l}\text { Pearson Correlation to } \\
\text { Active Frontage Rating }\end{array}$ & Significance (2-tailed) \\
\hline Safe-Unsafe & -0.305 & $0.000^{* *}$ \\
\hline Comfortable-Uncomfortable & -0.319 & $0.000^{* *}$ \\
\hline Sleepy-Lively & 0.257 & $0.000^{* *}$ \\
\hline Unfriendly-Sociable & 0.258 & $0.000^{* *}$ \\
\hline Noisy-Peaceful & -0.193 & $0.000^{* *}$ \\
\hline Pleasant-Unpleasant & -0.224 & $0.000^{* *}$ \\
\hline Relaxing-Exciting & 0.039 & 0.347 \\
\hline Convivial-Dull & -0.190 & $0.000^{* *}$ \\
\hline Active-Dormant & -0.329 & $0.000^{* *}$ \\
\hline Boring-Interesting & 0.168 & $0.000^{* *}$ \\
\hline This space makes me feel at ease & 0.241 & $0.000^{\star *}$ \\
\hline I like this space & 0.223 & $0.000^{* *}$ \\
\hline I would come here at night & 0.146 & $0.000^{* \star}$ \\
\hline I would meet my friends here & 0.135 & $0.001^{* *}$ \\
\hline I would come back here & 0.199 & $0.000^{* *}$ \\
\hline
\end{tabular}

$N=578$

Significance codes: * significant at the $5 \%$ level, ${ }^{* *}$ significant at the $1 \%$ level

Table 8: Correlation between Active Frontage Ratings and Respondents' Perceptions 